ELORE (ISSN 1456-3010), vol. 15 - 2/2008.

Julkaisija: Suomen Kansantietouden Tutkijain Seura ry.

[http://www.elore.fi/arkisto/2_08/kaa2_08.pdf]

KATSAUSARTIKKELI

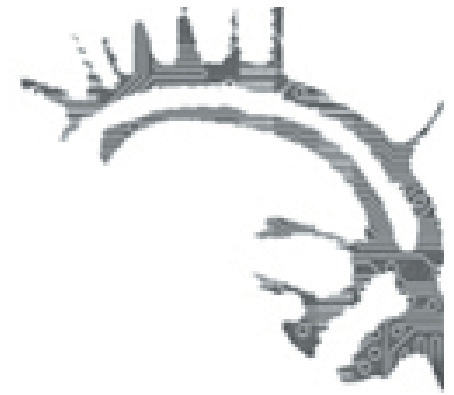

\title{
KERTOMUSKATEGORIAT JA LEHMÄN REPRESENTAATIOT KIRJOITUSKILPAILUTEKSTEISSÄ
}

\section{Taija Kaarlenkaski}

Kirjoituskilpailut ovat Suomessa suosittuja; muun muassa arkistot ja museot järjestävät niitä vuosittain ja niihin myös osallistutaan innokkaasti. Kirjoituskilpailun tuottama aineisto on tyypillisesti hyvin vaihtelevaa sekä teemoiltaan että kerrontatavoiltaan. Tässä kirjoituksessa tarkastelen yhden kirjoituskilpailun aineistoa ja siinä rakentuvia kertomuskategorioita. Kertomusten kategorisointi toimii pohjana pohdinnalleni siitä, miten kirjoitusten muoto tuottaa merkityksiä: miten lehmää ja ihmisen suhdetta siihen representoidaan eri tavoin rakennetuissa teksteissä. Kielellistetyt, kirjoitetut representaatiot lehmistä ovat yhteydessä kulttuuriseen ympäristöön ja yleisiin käsityksiin; ne voivat uusintaa mutta myös haastaa näitä käsityksiä. (Lehtonen 2004, 44-46; Rothfels 2002, xi). Aineistonani on Suomalaisen Kirjallisuuden Seuran ja Maaseudun sivistysliiton vuonna 2004 järjestämä Ei auta sano nauta - kirjoituskilpailu lehmästä. Kilpailun aineiston tekee kerronnallisesti erityisen kiinnostavaksi se, että siinä oli kaksi sarjaa, muistelukertomukset ja kaunokirjalliset tekstit. (1)

Tarkastelen kirjoituskilpailuun lähetettyjä tekstejä kertomuksina, joissa kirjoittajat käsittelevät kokemuksiaan ja niiden merkityksiä mutta myös käyttävät erilaisia kulttuurisia kerronnan malleja ja luovat kuvitteellisia maailmoja. (2) Lähtökohtani perustuu narratiiviseen näkemykseen kielellisestä merkityksellistämisestä ja siitä, että kertomukset ovat olennainen tapa tehdä maailmaa ymmärrettäväksi. (Ukkonen 2003; Lehtonen 2004, 30, 117; Abbott 2008, 1-12). Näen kertomukset konstruktivistisen tiedonkäsityksen mukaisesti todellisuutta tuottavina ja tulkitsevina, ei pelkästään sitä heijastavina (Riessman 1993, 4-5; Heikkinen 2000, 49-50; Ukkonen 2003). Monitieteisyydestään johtuen kerronnallisella tutkimuksella ei ole yhtenäistä teoriaa tai metodologiaa. Kirjoituksessani sovellan narratiivisen tutkimuksen näkökulmia erityisesti folkloristiikan, kirjallisuudentutkimuksen ja narratologian piiristä. (3)

Muistitieto ja erilaiset henkilökohtaiset kertomukset ovat olleet folkloristiikan tutkimuskohteina jo pitkään. Kirjoituksessani laajennan tarkastelua myös kaunokir- 


\section{KERTOMUSKATEGORIAT JA LEHMÄN REPRESENTAATIOT KIRJOITUSKILPAILUTEKSTEISSÄ}

jalliseen kehykseen kirjoitettuihin kertomuksiin. Niin sanotun kansan kirjoittamat fiktiotekstit ovat jääneet tutkimuksessa pitkälti paitsioon, sillä ne eivät ole kiinnostaneet folkloristeja "epäaitoutensa" vuoksi eikä niitä ole hyväksytty taidekirjallisuuden tutkimuksenkaan piiriin. (Kurki 2004, 69-70.) Kaikenlaiseen sepitteellisyyteen on Kansanrunousarkistonkin kokoelmissa suhtauduttu hyvin negatiivisesti perinteenkeruun alkuajoista lähtien (Pöysä \& Timonen 2004, 245-246). Kansanrunousarkiston tutkijan Juha Nirkon mukaan arkisto ei edelleenkään ota mielellään vastaan fiktiota, mutta Ei auta sano nauta -kilpailun kohdalla aineiston hajottaminen ei olisi ollut mielekästä eikä mahdollistakaan (Nirkko 2006). Kuitenkin elämme nykyisin kirjoituksen kulttuurissa, joten on luontevaa, että kirjoituskilpailuteksteissä hyödynnetään erilaisia kulttuurisia kertomusten malleja myös fiktion alueelta. Lisäksi fiktiossa voidaan ilmaista arvokasta kulttuurista tietoa, kuten arvoja, ihanteita ja toimintamalleja (Pöysä 1997, 300; Helsti 2005, 153).

Analyysini perustuu aineiston luokitteluun eri ryhmiin kertomusten kokonaishahmon (ks. Hyvärinen 2006, 26-29) perusteella. Narratiiviseen tutkimukseen suuntautunut psykologi Donald E. Polkinghorne on erottanut toisistaan narratiivien analyysin (engl. analysis of narratives) ja narratiivisen analyysin (engl. narrative analysis). Narratiivien analyysin tarkoituksena on kertomusmuotoisen aineiston luokittelu esimerkiksi teemojen tai kertomustyyppien perusteella, kun taas narratiivisessa analyysissä tutkija tuottaa uuden kertomuksen aineistonsa pohjalta. Tässä artikkelissa sovellan Polkinghornen ajatusta narratiivien analyysistä, jota hän nimittää myös paradigmaattiseksi analyysiksi. Tavoitteena ei tällöin ole vain kategorioiden löytäminen ja kuvailu vaan myös niiden välisten suhteiden havaitseminen. (Polkinghorne 1995, 12-14; ks. myös Heikkinen 2000, 52-53.) Tarkoitukseni ei ole etsiä kirjoituksista yleisiä kertomuksen rakenteen perusosia vaan muodostaa juuri Ei auta sano nauta -aineistoon perustuva jäsennys tarkastelemalla, millaisilla kerronnallisilla ratkaisuilla lehmästä kirjoitetaan ja millaista suhdetta lehmään kertomukset tuottavat. Olen muodostanut kategoriat lähilukemalla aineistoa eli käymällä kirjoituksia tarkasti läpi useita kertoja, kunnes luokitus tuntui saavuttaneen perustelluimman muotonsa (ks. Polkinghorne 1995, 13; Uotinen 2005, 97-98). Narratiivien analyysi soveltuu ennen kaikkea yleisten piirteiden ja teemojen pelkistämiseen aineistosta; kertomusten yksilölliset piirteet jäävät siinä vähäiselle huomiolle (Polkinghorne 1995, 14-15).

\section{KIRJOITUSKILPAILUTEKSTIT AINEISTONA}

Ei auta sano nauta-kirjoituskilpailun kirjoitusohjeissa korostettiin muistelukertomusten kohdalla kerrotun tosipohjaisuutta ja perustumista omiin kokemuksiin tai muistoihin. Toisaalta mainittiin, että arvioinnissa kiinnitettäisiin huomiota myös "kerrontatavan omaperäisyyteen". Kaunokirjallisen sarjan ohjeissa kehotettiin kirjoittamaan novelleja ja tarinoita, jotka arvioitaisiin kaunokirjallisina teoksina. (Ei auta sano nauta -kirjoituskilpailuesite, 2004.) Kertomuskategorioiden muodostamisen taustalla on näkemykseni siitä, että kirjoituskilpailun sarjajako muistelu- ja kaunokirjallisiin teksteihin on 


\section{TAJJA KaARLENKASKI}

kriteereiltään liian epämääräinen eivätkä sarjojen nimitykset anna juurikaan kuvaa kertomustyyppien moninaisuudesta.

Kirjoituskilpailun avulla kerätty aineisto on usein nähty eräänlaisena muistitietona (esim. Peltonen 1996; Pöysä 1997; Latvala 2005). Jyrki Pöysä on viitannut Alessandro Portellin (1998, 23-24) ajatukseen muistitiedosta "lajeista koostuvana lajina" ja jatkanut sitä eteenpäin luonnehtimalla kirjoituskilpailutekstiä "kertomusmuodoista koostuvaksi kertomukseksi”. Kuten Pöysäkin toteaa, kirjoituksissa hyödynnetään erilaisia suullisen ja kirjallisen kerronnan malleja laajasti, myös saman tekstin sisällä. (Pöysä 2006, 231-238.) Ei auta sano nauta -aineiston kirjoituksissa on käytetty esimerkiksi elämäkerrallisen kerronnan malleja, novellia, historiankirjoitusta, pakinaa ja jopa muistokirjoitusta. Näen nämä mallit Vilma Hännisen tapaan osana sosiaalista tarinavarantoa eli yksilölle tarjoutuvaa kulttuuristen kertomusten joukkoa. Ihmiset omaksuvat koko elämänsä ajan malleja tästä varannosta, johon kuuluvat niin sosiaalisessa vuorovaikutuksessa kuin mediassakin kohdatut kertomukset. (Hänninen 1999, 21; ks. myös Apo 1995, 231.)

Kirjoitusohjeilla ja keräävän arkiston herättämillä mielikuvilla on luonnollisesti vaikutusta kirjoituskilpailutekstien sisältöön. Kirjoituskutsu ja vastausteksti voidaan nähdä omina kirjoittamisen genreinään, jotka käyvät dialogia keskenään. (Peltonen 1996, 107-131; Pöysä 1997, 39-48; Latvala 2005, 33-36.) Kirjoituskilpailutekstejä tutkittaessa on otettava huomioon, että ne eivät ole syntyneet spontaanisti, pelkästään kirjoittajan omaehtoisena tuotoksena, vaan keruuilmoitus on antanut ainakin jonkinlaisen herätteen kirjoittamiseen. Ei auta sano nauta -kilpailun esitteessä oli useita valokuvia, joista monet viittasivat menneeseen suorastaan nostalgisesti, kuten käsinlypsy lehmisavulla ja iäkkäät ihmiset maitolaiturilla. Toisena järjestäjätahona toiminut Maaseudun Sivistysliitto on vahvasti ideologinen järjestö, jonka tavoitteena on muun muassa edistää maaseutukulttuuria alkiolaisen ja maahenkisen sivistyskäsityksen pohjalta (Maaseudun sivistysliitto 2008). Esimerkiksi nämä seikat ovat voineet ohjata kirjoittajien aihevalintoja ja tyyliä, mutta toisaalta ne ovat voineet herättää myös vastareaktioita.

Kirjoituskilpailuihin vastaajina on pidetty "tavallisia suomalaisia", keitä tahansa kilpailun teemasta kiinnostuneita. Vastaaminen on mahdollista, koska kirjoitusharrastus on Suomessa suosittua ja periaatteessa mahdollista jokaiselle. Kirjoittajien taidot ja taustat ovat kuitenkin hyvin vaihtelevia. (Hatakka 2004, 175; Taira 2006, 37-38.) Toisaalta monet tutkijat ovat arvioineet, että etenkin omaelämäkerrallisiin kilpailuihin valikoituisivat vastaajiksi erityisen "herkät" ja elämässään kriisejä kokeneet ihmiset (Roos 1987, 31; Apo 1995, 201; Pöysä 1997, 48-49). J. P. Roosin mukaan elämäkertansa kirjoittajat kuuluvat aina vähemmistöön, sillä suurin osa ihmisistä ei kirjoita omaelämäkertaa; kirjoittajat ovat eräänlaisia poikkeusyksilöitä (Roos 1987, 30). On myös muistettava, että kirjoituskilpailujen aiheet rajaavat vastaajien joukkoa. Tarkastelemaani kilpailuun osallistuivat sellaiset henkilöt, joille kirjoittaminen on luonteva tapa ilmaista itseään ja jotka kokivat lehmäaiheen syystä tai toisesta niin kiinnostavaksi että ryhtyivät kirjoittamaan. Tästä johtuen kirjoituskilpailulla saatu aineisto ei ole satunnaisotos, josta voitaisiin tehdä suoraviivaisia yleistyksiä sen sisäisten määrällisten suhteiden perusteella (Pöysä 1997, 48; Hänninen 1999, 109). 


\section{KERTOMUSKATEGORIAT JA LEHMÄN REPRESENTAATIOT KIRJOITUSKILPAILUTEKSTEISSÄ}

Ei auta sano nauta -kirjoituskilpailuun tuli vastauksia 2962 kappaletta ja aineistoa kertyi kokonaisuudessaan noin 11100 käsikirjoitusliuskaa. Olen lukenut näistä noin 480 kirjoitusta muistiinpanoja tehden. (4) Aineistoa lukiessani olen muodostanut käsityksen siinä esiintyvistä tyypillisistä teemoista ja kertomisen tavoista. Olen hyödyntänyt aineistonmuodostamisprosessissani saturaation ajatusta siinä mielessä, että olen tarkkaillut teksteistä muodostuvaa kokonaiskuvaa: uskon, että luettuani lähes 500 kirjoitusta täysin uudentyyppisiä tekstejä ei enää loppujen joukosta löydy. Myös kertomuskategoriat alkoivat hahmottua aineiston lukuprosessin aikana. (Ks. Taira 2006, 47-50; Laurén 2006, 72-74.) Lukemistani kirjoituksista olen valinnut varsinaiseen tutkimusaineistoon 126 tekstiä, joissa esiintyvät aineiston keskeiset teemat ja kertomustyypit. Tarkoitukseni ei kuitenkaan ole esittää väitöskirjassani aineistosta keskiarvoa vaan antaa tilaa kirjoittajien moninaisille tulkinnoille ja näkemyksille; mukana on myös teemoiltaan "valtavirrasta" poikkeavia kirjoituksia. Laajoja kirjoituskilpailuaineistoja tarkasteltaessa nouseekin tärkeäksi kysymykseksi se, kenen ääni pääsee kuuluville (Latvala 2002, 115, 118). Tässä kirjoituksessa en nosta esille yksittäisiä kirjoituksia vaan pyrin aineistolainauksilla havainnollistamaan eri kertomuskategorioiden piirteitä.

\section{KERRONNALLINEN TUTKIMUS NÄKÖKULMANA KIRJOITUSKILPAILUAINEISTOON}

Narratiivisen tutkimuksen kohteena on kertomus itsessään, joko kerrontatapahtumana tai valmiina esityksenä (Riessman 1993, 1; Hänninen 1999, 30-31; Kreiswirth 2005, 377). Kirjoituksessani tarkastelen aineistoani valmiina kertomuksina, jotka on tuotettu kirjoituskilpailun kontekstissa. Kirjoitetun tekstin välityksellä voi saada tietoa myös kerronnasta eli kertomuksessa olevan tarinan tuottamisprosessista. Kerronnan alueelle kuuluvat esimerkiksi erilaiset kertojatyypit, aikasuhteet ja puheen esittämisen tavat. (Rimmon-Kenan 1991, 10,114-148.) Tarkastelussani keskeisemmällä sijalla ovat kertomusten kokonaisuudet ja niiden jäsentyminen kategorioiksi, vaikka viittaankin niitä määritellessäni myös kerronnallisiin ratkaisuihin. Kertojalla tarkoitan kertomuksessa puhuvaa ääntä, en tekstin fyysistä tekijää, johon viittaan termillä kirjoittaja (RimmonKenan 1991, 113). Myös omaelämäkerrallisesti kirjoittava luo tekstiinsä kertojan, sillä kirjoittaminen edellyttää jatkuvia valintoja; kaikkea ei voi koskaan kertoa (Vainikkala 1998; Saresma 2007, 62-64).

Kertomukseen yleisesti liitettyjä piirteitä ovat ajallinen muutos, toiminta ja toisiinsa kausaalisesti liittyvien tapahtumien kuvaus. Kertomuksen minimivaatimuksena on esitetty, että se sisältää jonkin tapahtuman tai tapahtumasarjan. Toisaalta se voi olla myös laaja ja monia erilaisia puhetapoja sisältävä, kuten romaani. (Rimmon-Kenan 1991, 8-9; Hyvärinen 2006, 4-5; Abbott 2008, 13.) Tällaisia ovat usein myös kirjoituskilpailutekstit. Aineistoni kontekstissa määrittelen kertomuksen tekstikokonaisuudeksi, jossa tapahtumille annetaan ajallinen järjestys ja jossa toimii ihmisenkaltainen kokija (ks. Fludernik 1996, 12-13). Kirjoituskilpailutekstin voi nähdä kokonaisuudessaan kertomuksena, joka useimmiten jakautuu lyhyempiin osakertomuksiin. Pidän hedel- 


\section{TAJJA KaARLENKASKI}

mällisenä Jyrki Pöysän näkemystä siitä, että narratiivisuus toteutuu kilpakirjoituksissa monilla tasoilla: helposti kertomuksiksi hahmottuvien tapausmuotoisten kertomusten lisäksi kirjoituksiin voi sisältyä kuvauksia, jotka eivät välttämättä täytä erillisen kertomuksen kriteerejä. Yhdessä nämä eri tasot kuitenkin muodostavat kirjoituksen kertomuksellisen aineksen. (Pöysä 2006, 236-237.)

Kerronnan teoriat on pääasiassa kehitetty kaunokirjallisuuden (narratologia) tai suullisten kertomusten (sosiolingvistiikka, folkloristiikka) tutkimukseen, mikä tekee niiden soveltamisen harrastajakirjoittajien teksteihin jossain määrin ongelmalliseksi. Narratologian käsitteet ja menetelmät pohjautuvat kerrontarakenteiltaan monimutkaisista fiktioteoksista tehtyihin analyyseihin. Vaikka kirjoituskilpailutekstit harvoin ovat yhtä monitasoisia, monet narratologian peruskäsitteet ovat käyttökelpoisia apuvälineitä myös niiden tarkastelussa. Toisaalta suullisetkin kertomukset eroavat kirjoituskilpailuteksteistä monin tavoin. Jyrki Pöysän mukaan keskeisimpiä kirjoitetun kerronnan erityispiirteitä ovat yksityisyys, suoran vuorovaikutuksen ja sen myötä haastattelijan ohjailumahdollisuuden puuttuminen, tekstin editoimisen ja kirjoittamisen ajankohdan ja paikan valitsemisen mahdollisuus sekä kuvitteellisen vastaanottajan korostuminen tekstiin kirjoitettuna lukijana (Pöysä 2006, 229). Suulliset kertomukset ovat usein kirjoitettuja spontaanimpia ja hajanaisempia; kirjoittaminen mahdollistaa mietityn muodon ja tekstin korjailun. Puhutuilla ja kirjoitetuilla kertomuksilla on myös yhteisiä piirteitä: esimerkiksi puheen prosodiaa voivat vastata erilaiset tekstin korostustavat, kuten lihavointi tai kursivointi (Lehtonen 2004, 79). Muitakin puheen keinoja, kuten murretta, voidaan hyödyntää kirjallisissa kertomuksissa.

\section{KertomusKategoriat EI AUTA SANO NAUTA -KIRJOITUSKILPAILUN AINEISTOSSA}

Muodostamani neljä kertomuskategoriaa ovat omaelämäkerralliset kertomukset, etnografiset kertomukset, lehmänäkë̈kulmaiset kertomukset ja fiktivoidut kertomukset. Kategorioiden rakentumista ovat ohjanneet aiemmat samantyyppisistä aineistoista tehdyt jäsennykset (5) sekä oma tietämykseni erilaisista kertomustyypeistä. Tarkastelussani olen ottanut huomioon kertomusten sekä muodolliset että sisällölliset piirteet, sillä ne vaikuttavat oleellisesti toisiinsa (Pöysä 2003, 150). Esimerkiksi omaelämäkerrallisia ja lehmänäkökulmaisia kertomuksia ei välttämättä erota toisistaan pelkkien muodollisten piirteiden perusteella, mutta erot näiden kirjoitustyyppien merkityksissä ovat olennaisia. Tarkoituksenani ei ole laatia yksittäisten kirjoitusten osalta tarkkaa luokitusta tiettyyn kertomuskategoriaan vaan tunnistaa keskeisimmät kertomustyypit ja niiden tuottamat merkitykset. Kategorisointini onkin lähinnä typologinen: samassa kirjoituksessa voivat yhdistyä usean kertomuskategorian piirteet. Kategoriat muodostavat eräänlaisen vuorovaikutteisen verkoston, jossa kerronnan keinoja ja tyylipiirteitä lainaillaan ja yhdistellään. (Ks. Lyytikäinen 2005, 10-11.)

Eri kertomuskategorioita edustavien kirjoitusten väljät määrälliset osuudet ovat tutkimusaineistossani seuraavat: omaelämäkerralliset kertomukset 83 kirjoitusta, 


\section{KERTOMUSKATEGORIAT JA LEHMÄN REPRESENTAATIOT KIRJOITUSKILPAILUTEKSTEISSÄ}

etnografiset kertomukset kolme kirjoitusta, lehmänäkökulmaiset kertomukset 18 kirjoitusta ja fiktivoidut kertomukset 22 kirjoitusta. Omaelämäkerrallisten kertomusten suuri osuus juontuu kirjoituskilpailun muistelusarjasta, jossa painotettiin omakohtaisuutta. Muistelua tai kokemuksia korostavat keruuohjeet tuottavat yleensäkin vastauksiksi myös omaelämäkerrallisia kuvauksia (Poysä \& Timonen 2004, 241). Jyrki Pöysän mukaan kirjoittamisen mahdollisesti pitkäkestoinenkin prosessiluonne suorastaan kannustaa omaelämäkerralliseen kerrontaan, jos kohta kirjoittaminen voi edistää myös kerronnan fiktiivisyyttä (Pöysä 2006, 230-231). Kokonaisuudessaan etnografisiksi kertomuksiksi jäsentyviä kirjoituksia on tutkimusaineistossani ainoastaan kolme, mutta monien omaelämäkerrallisten kertomusten yhteydessä esiintyy etnografisia jaksoja. Omaelämäkerralliset kertomukset ovat selvästi yleisempiä kuin kuvitteellisuuteen painottuvat lehmänäkökulmaiset ja fiktivoidut kertomukset yhteensä. Omakohtaisuus, todenmukaisuus ja tuttuus ovat suomalaisten myös kirjallisuudessa arvostamia piirteitä (Jokinen 1997, 43-45).

\section{Omaelämäkerralliset kertomukset}

Omaelämäkerralla tarkoitetaan yleensä minämuotoista kronologisessa järjestyksessä etenevää proosakertomusta, jossa kirjoittaja kertoo elämästään kirjoitushetken näkökulmasta katsottuna (Lejeune 1989, 4-5; Makkonen 1993, 10). Omaelämäkerran käsitteen sijasta käytän omaelämäkerrallista kertomusta, sillä omaelämäkerta herättää helposti mielikuvan laajasta ja monivaiheisesta esityksestä, jossa käydään läpi kirjoittajan koko siihenastisen elämän merkittävimmät tapahtumat ja kokemukset (ks. Hynninen 2004; Latvala 2005, 72). (6) Näin ei kuitenkaan Ei auta sano nauta -kirjoituskilpailun teksteissä usein ole vaan kirjoittajat voivat keskittyä pelkästään lapsuuteen tai johonkin muuhun elämänvaiheeseen. Tähän vaikuttaa kilpailun teema: kirjoitetaan niistä vaiheista elämässä, joihin lehmä on liittynyt jollakin tavalla. Monissa kirjoituksissa kertovan minän lisäksi keskeisessä asemassa ovat elämän varrella kohdatut "lehmäpersoonat". Nämä eläimet saatetaan muistaa hyvinä ja kaivattuina ystävinä - tai unohtumattomina kiusankappaleina.

Sitten oli Kaunis lempinimi Kauno, joka oli omana aikanaan ebdoton jobtaja ja oikea persoona, minulle lempeä ja kiltti, sillä olinhan ottanut "roolini" sen ollessa vasikkea, mutta ovela. Sillä oli ibmeellinen vaisto. Kun lähdin kotoa johonkin, niin varmasti se oli pois laitumelta viljapellossa tai muussa pabanteossa, eikä millään meinanneet saada sitä takaisin aitaukseen. Se pelotteli aidan ulkopuolellakin kulkijoita jos vähänkin oli arka, se juoksi aituvartta möyrysi, puski turvetta ja kaapi maata. Myöhemmin siihen tulikin sonnitauti n.s. möyrytauti. Kun lehmät vietiin pihanreunaa pitkin laitumelle, niin Kauno oli aina "eka" ja voi veljet jos pyykekiä oli narulla; "Yhekerran ku sen silmät väläht" ja se läbti juoksuun, buiski niitä sarvillaan sen kun kerkesi ja sai kun saikin jotain, kerrankin isännän kalsarit sarviinsa ja nïden kanssa se juoksiympäri laidunta, ikäänk.uin esitelläkseen. (SKS KRA. Ei auta sano nauta 390, 2; nainen 72 v.) (7) 


\section{TAJJA KaARLENKASKI}

Suurimman osan omaelämäkerrallisiksi kertomuksiksi määrittelemistäni kirjoituksista kirjoittaja itse on ilmoittanut muistelukertomusten sarjaan. Sarja on usein mainittu kirjoituksen ensimmäisellä sivulla joko otsikon yhteydessä tai erillisenä huomautuksena. Vakuutus kerrotun kokemuspohjaisuudesta voidaan ilmaista myös varsinaisen tekstin alussa tai lopussa: "Tämä minun tarinani naudasta tai nimenomaan lehmästä perustuu omaan kokemukseeni ja muistoihini samalla" (SKS KRA. Ei auta sano nauta 1419, 1; nainen 54 v.). Kirjoittajan tekemä sarjavalinta tai vakuuttelu omakohtaisuudesta voidaan nähdä eräänlaisena omaelämäkerrallisena sopimuksena, jolla viitataan siihen, että lukija ymmärtää tekstin kirjoittajan, kertojan ja päähenkilön olevan sama henkilö (Lejeune 1989, 14). Kaikki kirjoittajat eivät kuitenkaan ole määritelleet kirjoituksensa sarjaa tai muuten korostaneet sen kokemuspohjaisuutta. Näenkin omaelämäkerrallisen kertomuksen myös muotoon viittaavana käsitteenä: jos se määritellään minämuotoiseksi kertomukseksi, jossa kertoja käy reflektiivisesti läpi elämänsä vaiheita, ei tarvitse välttämättä ottaa kantaa siihen, ovatko kertoja ja kirjoittaja sama henkilö. Teemu Taira onkin huomauttanut, että omaelämäkerrallisen sopimuksen käsite on tarpeeton, jos kirjoituksista ei etsitä aitojen kokemusten tai todellisten tapahtumien kuvausta (Taira 2006, 44).

Ensimmäisen persoonan hallitsevuudesta huolimatta persoonamuotoja voidaan vaihdella kesken tekstin. Esimerkiksi 83 -vuotias mies päättää minämuodossa edenneen kertomuksensa lapsuuden paimenkesistä kuvaamalla itseään kolmannessa persoonassa vanhana miehenä, joka kulkee entisiä metsittyneitä paimenpolkuja (SKS KRA. Ei auta sano nauta 79, 5; mies 83 v.). Tällainen kerronnallinen ratkaisu korostaa omaelämäkerran minän jakautumista. Kolmannen persoonan käytöllä tuodaan esille, että 13-vuotias paimenpoika ja lapsuuden maisemia katseleva vanha mies ovat ikään kuin eri henkilöitä. (Makkonen 1993, 16; Saresma 2007, 62-63.) Ulkopuoliseen näkökulmaan ja kolmannen persoonan käyttöön voidaan turvautua myös silloin, kun kirjoittaja kertoo ajasta ennen syntymäänsä tai aivan varhaisimmasta lapsuudestaan (esim. SKS KRA. Ei auta sano nauta 149,1; nainen 86 v.). Tällöin ei rikota sitä omaelämäkerran konventiota, että kertoja ei voi kuvata asioita, joita ei ole itse kokenut. (Makkonen 1993, 16-17.) Erkki Vainikkalan $(1998,454)$ mukaan omaelämäkerrallinen sopimus ei purkaudu, vaikka kirjoituksessa käytettäisiin kolmatta persoonaa, koska sitä luetaan edelleen kirjoittajan elämäntarinana.

Omaelämäkerrallisissa kertomuksissa kerrottu aikajakso vaihtelee. Tuija Saresma on käyttänyt termiä omaelämäkerrallinen fragmentti, jossa kuvataan yhtä hetkeä, kokemusta tai elämystä. Näissä fragmenteissa ei useinkaan noudateta omaelämäkerta-genren sääntöjä, kuten kronologisuutta. (Saresma 2007, 119.) Ne muistuttavat myös Kirsti Salmi-Niklanderin muotoilemaa tapahtumakerronnan käsitettä, jolla hän tarkoittaa kertomuksia "pienistä" toistuvista tapahtumista, jotka kuitenkin poikkeavat tavallisesta arjen kulusta (Salmi-Niklander 2004, 173). Ei auta sano nauta -aineistossa kerrotaan esimerkiksi erilaisista huvittavista tai dramaattisista tapauksista, kuten lehmien karkaamisesta laitumelta tai erikoisen vaikeista poikimisista. Fragmenteissa esiintyy lehmään liittyvien kokemusten ja tunteiden koko kirjo: koomiset tilanteet, menetykset, vaikeudet ja yllätykset. Omaelämäkerrallisella fragmentilla on yhtymäkohtia myös muiston käsitteeseen, jossa korostuvat tunnepitoiset ja aistimukselliset elämykset. 


\section{KERTOMUSKATEGORIAT JA LEHMÄN REPRESENTAATIOT KIRJOITUSKILPAILUTEKSTEISSÄ}

Muistoihin voi liittyä vahva tunne siitä, että muistettu vastaa yksityiskohtaisesti todella tapahtunutta. (Korkiakangas 2005, 134.) Tällöin voidaan myös omaelämäkerrallisille kertomuksille tyypillisen imperfektin sijasta käyttää preesensiä, mikä vahvistaa vaikutelmaa tilanteen uudelleen kokemisesta muisteluhetkellä:

Jos nyt laittaisin valot päälle, lehmät nousisivat ylös ja alkaisivat ammua ruokaa odottaen. Astelen kuitenkin hämärässä hiljaa kohti vasikoiden karsinoita. Yhdessä karsinassa on pieni, eilen syntynyt, vasikeka joka buomaa minut kun lähestyn karsinaa. Se säntää pystyyn ja tulee innokekaasti imemään sormiani maidon toivossa. Moni vasikek on imenyt sormeni ihan kipeiksi, vaikkei niillä ole edessä hampaita kuin alhaalla. Rapsutan vasikeka. Terve se on, ja reipas. Pieni musta lebmävasikeka omassa karsinassaan. Vasikeka alkaa mölistä kun se oikein innostuu, ja lebmät vastaavat kuullessaan elänlapsen äänen. Vasikan nimi on Taffeli. (SKS KRA. Ei auta sano nauta 537,2; nainen 28 v.)

Omaelämäkerrallinen fragmentti voi esiintyä pitempää aikajaksoa kuvaavan omaelämäkerran osana tai yksittäisen kirjoituksen pääsisältönä. Kirjoitus voidaan rakentaa myös episodimaisesti erillisistä fragmenteista.

Olen jakanut omaelämäkerralliset kertomukset kolmeen alakategoriaan: "kokonaisiin" omaelämäkertoihin (tutkimusaineistossa 29 kirjoitusta), jotka kuvaavat kertojan elämää lapsuudesta kirjoitushetkeen, "elämänvaihekertomuksiin", joissa kerrotaan esimerkiksi vain lapsuudesta (47 kirjoitusta), ja omaelämäkerrallisiin fragmentteihin (7 kirjoitusta). Kokonaisissa omaelämäkerroissa hahmotetaan tavallisesti karjanhoitajien kokemuksia lapsuudesta aikuisuuteen tai eläkepäiviin saakka. Näissä kirjoituksissa usein pohditaan myös karjataloudessa ja laajemmin maatalouspolitiikassa vuosikymmenien aikana tapahtuneita muutoksia ja kritisoidaan nykyistä tehokarjanhoitoa. Kokonaisissa omaelämäkerroissa, samoin kuin elämänvaihekertomuksissa, keskeisenä teemana on työnteko lehmien parissa. Lapsuuteen keskittyvissä kertomuksissa kerrotaan esimerkiksi lypsämään opettelusta, paimenessa olosta ja muista karjanhoitoon liittyvistä avustavista tehtävistä. Lapsuuteen sijoittuvien kertomusten runsas määrä kertoo omalta osaltaan siitä, miten suurella joukolla suomalaisista on juuret maaseudulla ja sitä kautta myös kerrottavaa lehmistä.

\section{Etnografiset kertomukset}

Etnografisilla kertomuksilla viittaan kirjoituksiin, jotka keskittyvät esimerkiksi karjanhoitoon liittyvien työtapojen ja -ympäristöjen tai rakennusten suhteellisen tarkkaan kuvailuun. Kertomusten etnografisuudella tarkoitan samankaltaisuutta niin sanottujen kansankirjailijoiden tai etnografisten kirjailijoiden tekstien kanssa (ks. Apo 2001, 90), en niinkään tieteellisten etnografioiden kanssa. Nämä tekstit ovat verrattavissa Pauliina Latvalan näkemykseen perustietojen antajan kirjoittamispositiosta: asioista kirjoitetaan yleisestä näkökulmasta, tunteista ei juurikaan kerrota ja persoonamuotona käytetään usein passiivia. Tällaisen harrastajahistorioitsijan tavoitteena on entisistä ajoista ker- 


\title{
TAJJA KaARLENKASKI
}

tominen ja tiedon välittäminen laajalle yleisölle. (Latvala 2005, 64-65.) Etnografisissa kertomuksissa voi olla opettavaa sävyä: lukijoiden ei oleteta tuntevan karjanhoidon työvälineitä ja -tapoja, joten niitä kuvataan ajoittain hyvinkin yksityiskohtaisesti. Näissä kertomuksissa kertojan minä on vähäisessä roolissa ja kerronta etäistävää (vrt. Siikala 1984, 132, 161). (8) Esimerkiksi "Lapsuuden muistoksi” otsikoidussa kertomuksessa kertojan oma kokemus tulee esille vain muutamissa kohdissa:

\begin{abstract}
Mökissä elettiin täysin luontaistaloutta. Seurattiin kunnkiertoa täbtien asentoja sekä seurattiin monia luonnon ennusmerk.kejä. Allakeka kului käytössä, siitä katsottiin tähtimerkkejä. Mitään ratkaisevaa työtä ei ryhdytty aloittamaan alapuoleen kunta. Lampaat kerittiin aina yläpuoleen kuun samoin perunan kylvöpäivä katsottiin allakasta, ei niinkeään säiden mukaan. ja satoa saatiin aina.

Keväällä lebmien poijittua maitoa alkoi olla runsaammin. Nukkuessani undessa pirtissä aamu unen läpi alkoi kuulua separaattorin voimistuva burina. Maitokone, joksi separaattoria sanottiin oli ruwvattu tukevasti ovensumpenkkiin kiinni vanhanpirtin puolelle. Tarvittiin melkoiset kierrokset kunnes maito alkoi haljeta kermaksi ja kurriksi. Menin unisena seuraamaan maidon laskua, minulle oli varattu pöydän nurkalle mukillinen lypsylämmintä maitoa. (SKS KRA. Ei auta sano nauta 295, 4; mies $58 \mathrm{v}$.
\end{abstract}

Passiivin avulla voidaankin saada aikaan mielikuvia kollektiivisuudesta (Latvala 2005, 45): etnografisilla kertomuksilla luodaan vaikutelmaa siitä, että näin on tehty yleisesti.

Jotkut kirjoittajat ovat osallistuneet sekä muistelu- että kaunokirjalliseen sarjaan. Eräs heistä on erottanut tekstinsä toisistaan tyylillisesti kirjoittamalla muistelukertomusten sarjaan omaelämäkerrallisen kertomuksen vaiheistaan lapsuuden pientilalta oman karjan omistajuuteen ja siitä luopumiseen, kun taas kaunokirjalliseen sarjaan lähetetty kirjoitus käsittelee karjanhoitoa yleisemmällä tasolla. Kirjoittajan sarjavalinnasta huolimatta näen jälkimmäisen lähinnä etnografisena kertomuksena, sillä sen tyyli on selonteonomainen ja passiivia käytetään runsaasti. Esimerkiksi muistelusarjan tekstissä kertoja kuvailee seikkaperäisesti lapsuuden evakkomatkoja Karjalasta ja perheen myöhempää asettumista Hämeeseen; sen sijaan etnografisessa kertomuksessa vertaillaan yleisesti karjalaisten ja hämäläisten karjanhoitotapoja ilman viittausta evakkokokemuksiin. (SKS KRA. Ei auta sano nauta 762 ja 763; mies 72 v.)

Omaelämäkerrallisten kertomusten lomassa esiintyvissä etnografisissa jaksoissa voidaan kuvailla tarkasti vaikkapa navettaa tai lehmien laidunta ja sen ympäristöä. Välttämättä etnografiset kertomukset eivät paikannu etäiseen menneisyyteen vaan kuvatut asiat voivat sijoittua myös nykypäivään:

\footnotetext{
Nïn kauan kuin muistan, meillä on aina ollut lehmiä. [...] Kotini navetta on noin vuonna 1915 rakennettu parsinavetan ja tallirakennuksen ybdistelmä. L-kirjaimen muotoinen, jonka toisessa siivessä on navetta ja toisessa talli. Talliin kuului aikanaan valjashuone, joka sittemmin on munttunut autotalliksi. Toki navettaa on remontoitu useaan kertaan eri vuosikymmenien vaatimuksia vastaavaksi. Tietyt peruspiirteet tosin ovat säilyneet alusta asti. Näin oletan. (SKS KRA. Ei auta sano nauta 680,1 ; mies 29 v.)
} 


\section{KERTOMUSKATEGORIAT JA LEHMÄN REPRESENTAATIOT KIRJOITUSKILPAILUTEKSTEISSÄ}

Omaelämäkerrallisten kertomusten lomassa etnografinen ote häivyttää minän joksikin aikaa taka-alalle ja huomio kiinnittyy ympäristöihin tai työtapoihin. Erityisesti keskittyessään maisemiin se lähenee kuvausta, jota on luonnehdittu staattiseksi ja visuaaliseksi tekstin osaksi, jossa kerronta ei etene ajallisesti (Hyvärinen 2006, 5; Wolf 2007, 35). Etnografisissa kertomuksissa ja jaksoissa ei tarkkaan ottaen ole kysymys itse lehmästä vaan pikemminkin lehmän erilaisista konteksteista.

\section{Lehmänäkökulmaiset kertomukset}

Lehmän näkökulmasta kirjoitetut kertomukset on kerrottu joko ensimmäisessä persoonassa, jolloin kertojana on lehmä itse, tai kolmannessa persoonassa lehmän kautta fokalisoituna. (9) Tällöin kertoja on niin sanottu kaikkitietävä kertoja, joka ei osallistu tarinan tapahtumiin ja joka pystyy kertomaan kuvaamiensa henkilöiden ajatuksista ja tunteista (Rimmon-Kenan 1991, 120-122). 'UUlkona oli virikkeitä koko rahan edestä ja lehmiä alkoi heikottaa. Sorkat tuntuivat punteilta, päässä jyskytti juoksevien jalkojen töminä ja nielua kuivasi." (SKS KRA. Ei auta sano nauta 487, 6; nainen 35 v.) Lehmänäkökulmaisten kertomusten esikuvina voi pitää eläinsatuja, eläinnäkökulmaista kaunokirjallisuutta sekä piirrettyjä elokuvia. Kertomuksissa voidaan lainata elämäkerran konventioita ja rakenteita; lehmä voi kertoa itse koko elämästään tai osasta sitä.

Olen lebmä nimeltä Mansikki. Synnyin keskellä kylmintä talvea pakkasen paukkuessa ja jäädyttäessä navetan ikkunat tammikuussa vuonna 1998. Ensimmäinen tutustumiseni maailmaan oli valitettavasti "sontaloori", koska oli aamuyö ja lehmien boitajat nukkuivat sikeästi niin kuin ibmisten kunlunkin nukkua yönsä hyvin. Nyt olen jo kuusivuotias. Jos olisin ibminen, olisin esikouluikeäinen, mutta lebmäksi olen jo keski-iän ylittänyt yksilö. (SKS KRA. Ei auta sano nauta 328,1; nainen $40 \mathrm{v.})$

Tavallista on, että nautojen ja ihmisten käyttäytymistä ja elinoloja vertaillaan, usein ihmisiä kritisoiden ja ironisoiden. Perspektiivin vaihtaminen eläimeen antaa mahdollisuuden tarkastella ihmisen toimintaa ikään kuin ulkopuolelta, toisesta näkökulmasta. Ironia ja huumori perustuvat maailmojen vastakkaisuuteen ja roolien vaihtumiseen (ks. Tarkka 2005, 262). Kritiikki karjanhoidon muutoksia ja lehmien elinoloja kohtaan voikin olla jopa kovempaa kuin omaelämäkerrallisessa kerronnassa.

Lehmää kertojana käytettäessä korostetaan eläimen yksilöllisyyttä antamalla sille oma ääni. Tällä tavalla painotetaan, että naudat eivät ole laumaeläinten massaa vaan yksilöitä, joilla on erilaisia tarpeita ja ajatuksia.

En voi pubua kaikkien puolesta, enkä edes halua. Monet meistä tuntuvat viibtyvän ihan hyvin. Ovat jopa onnellisia undessa elämäntyylissään, mutta minulle tämä on kaubeata. Olen aina rakastanut kiireettömyyttä, rauhallisuntta ja läheistä kontaktia. [...] Minä en kestä muntosta, joka tuntuu vievän minulta yksilöllisyyden. En kestä sitä että minut painetaan samaan muottiin kaikkien kanssa. En halua olla "yksi 


\title{
TAJJA KaARLENKASKI
}

\author{
heistä", haluan olla MIN Ä. Haluan että minut tunnetaan. (SKS KRA. Ei auta \\ sano nauta 2519, 3; nainen 20 v.)
}

Antropomorfismi eli ihmisenkaltaistaminen tulee selvästi esille lehmänäkökulmaisissa kertomuksissa: eläimiin liitetään ihmisen ominaisuuksia tai piirteitä (Daston \& Mitman 2005, 2). Naudat voidaan kuvata tuntevina olentoina, jotka esimerkiksi surevat eroa vasikoistaan, iloitsevat päästessään keväällä ulos, ovat kateellisia ja kokevat jopa romanttisia ja seksuaalisia tunteita. Toisaalta tällaiset kuvaukset voi nähdä "ajattelemisena eläinten kanssa" (thinking with animals): kirjoittajat ovat pohtineet, miltä naudasta voisi tuntua ja mitä se saattaisi ajatella (Daston \& Mitman 2005, 10).

Lehmänäkökulmaisissa kertomuksissa voi esiintyä myös sadunomaisia aineksia, kuten nautojen puhuminen keskenään ihmisten kielellä. Sanonta lehmien lentämisestä on ilmeisesti antanut useille kirjoittajille aiheen kertomuksille lentoon lähtevän lehmän seikkailuista. Tämän tyyppisissä eläinsatua yhtenä kerronnan mallina käyttävissä kertomuksissa ihmiset on usein häivytetty taka-alalle tai he puuttuvat kokonaan. Tällöin nautojen kuvaus voi saada jopa utooppisia ulottuvuuksia: ne elävät onnellista perhe-elämää ilman ihmisiä ja maidon- tai lihantuotantoa. Lehmänäkökulmaisen kerronnan voikin karkeasti jakaa kahteen ryhmään: realistisiin kertomuksiin, joiden pohjana on naudan asema koti- tai tuotantoeläimenä, ja fantasiakertomuksiin, joissa tämä asema ylitetään.

\section{Fiktivoidut kertomukset}

Kaunokirjallisuuteen yhdistettyjen kerronnallisten keinojen käyttö on varsin yleistä kirjoituskilpailuteksteissä. Jyrki Pöysä $(2003,155)$ on kiinnittänyt huomiota teksteissä ajoittain esiintyvään "novellistiseen" tyyliin, jolle on ominaista esimerkiksi dialogin runsas käyttö. Dialogin lisäksi fiktiiviselle kerronnalle tyypillisinä piirteinä on pidetty esimerkiksi näkökulman vaihdoksia, vapaata epäsuoraa esitystä ja kielellisten symbolien käyttöä (Lehtimäki 2000, 50). Tämäntyyppisistä kertomuksista käytän nimitystä fiktivoidut kertomukset. Tähän kertomuskategoriaan olen sisällyttänyt kirjoituksia, joissa kerrottua on selvästi etäännytetty kaunokirjallisen kerronnan keinoin, esimerkiksi käyttämällä kolmatta persoonaa ja kaikkitietävää kertojaa. Fiktivoiminen voi viitata myös kertomuksen sijoittumiseen selkeästi fiktiiviseen aikaan tai paikkaan. (Ks. Salmi-Niklander 2004, 140, 161, 177-179.) Myös minäkertoja voi olla fiktiivinen, vaikkapa navettatonttu. Osan näistä teksteistä myös kirjoittajat itse ovat sijoittaneet kaunokirjalliseen sarjaan.

Kirjallisuudentutkija Dorrit Cohn määrittelee fiktion kertomukseksi, jonka viittauksien tekstin ulkopuoliseen maailmaan ei tarvitse olla paikkansapitäviä ja joka ei viittaa pelkästään tekstin ulkopuoliseen maailmaan. Fiktion erityispiirteitä ovat hänen mukaansa kertojan mahdollisuus kuvata toisten ihmisten sisäistä maailmaa, kertojan äänen jakautuminen (tekijä on eri kuin kertoja) sekä kertomuksen esitysjärjestyksen ja kerrotun tapahtumasarjan erottaminen toisistaan. (Cohn 2006, 25, 130-154.) Toisaalta fiktivoimisen voi nähdä myös erityisenä kaunokirjallisena kielenkäyttötapana 


\section{KERTOMUSKATEGORIAT JA LEHMÄN REPRESENTAATIOT KIRJOITUSKILPAILUTEKSTEISSÄ}

venäläisen formalismin näkemyksien mukaisesti (Eagleton 1996, 2; Korsisaari 2003, 291). (10) Kaunokirjallisuus-termillä voidaan viitata korkeatasoiseen sanataiteeseen (Hosiaisluoma 2003, 405), mikä käy ilmi myös Ei auta sano nauta -kilpailun kirjoitusohjeista: kaunokirjalliseen sarjaan kehotettiin kirjoittamaan esimerkiksi novelleja.

Esimerkkeinä kerronnallisesta etäännyttämisestä voi mainita kaksi kirjoitusta, jotka on ilmoitettu muistelukertomusten sarjaan mutta jotka on kerrottu käyttäen kaikkitietävää kertojaa. Molemmat kertomukset kuvaavat Lapin sotaa, siihen liittyneitä evakkomatkoja ja evakossa olleita lehmiä varsin dramaattisin kääntein. Kerronnassa voidaan välillä piipahtaa myös nykyhetkessä:

\section{Nyt, kuusikymmentä vuotta myöhemmin, evakkoon itsensä ja kaksi lastaan pa- kannut emäntä muistelee lähtöä samassa keltaiseksi maalatussa talossaan. Tuki- rangastaan kasaan painuneena, metallimöllykät lonkissa kolottaen bän muistelee tuota päivää ja sitä seuranneita molotovin verhojen pimentämiä öitä. (SKS KRA. Ei auta sano nauta 2818, 2; nainen 34 v.)}

Vasta kertomuksen viimeisessä lauseessa paljastuu, että kuvattu päähenkilö on kirjoittajan mummo. Toisen kirjoituksen lopussa taas luetellaan siinä käytetyt lähteet, joita ovat haastattelu, kuntahistoriikki ja "kyläläisten keskuudessa elävä tosipohjainen tarina” (SKS KRA. Ei auta sano nauta 265, 8; mies 78 v.). Muistelukertomusten sarjalla kirjoittajat ovat ilmeisesti halunneet korostaa kertomustensa kokemuspohjaisuutta valitusta kerrontatekniikasta huolimatta.

Fiktivoituihin kertomuksiin sisältyy kiinnostavia kertomusmallien yhdistelmiä. Eräs kirjoittaja on esimerkiksi antanut tekstilleen alaotsikon "tosipohjainen novelli". Kertomuksessa käytetään alusta asti runsaasti dialogia ja elävöittäviä murreilmaisuja:
Se oli sitä aikaa kun meistä tuli maanviljelijöitä ihan kertabeitolla. Se tapabtui kuin salamaniskusta. Isä oli menettänyt kaiken omaisuntensa ja ammattinsa sodan melskeissä ja bänelle tarjottiin vastikkeeeksi maatilaa jostakin helskutin korvesta. - Minä taidan ottaa sen, isä sanoi kun oli saanut siitä tiedon.
- Hullu mies, mitä sie sillä, äiti toppuntteli.
- Alan maanviljelijäksi tietenki, isä vastasi.
- Maanviljelijäksi, äiti kiljabti. - Mitästä bulluja alat, eibän myö mittään maan- viljelijöitä olla oltu. (SKS KRA. Ei auta sano nauta 20, 1; mies 67 v.)

Kertomuksessa omakohtaisuutta tuodaan esiin käyttämällä ajoittain me-muotoa ja ensimmäistä persoonaa. Minäkertoja kuitenkin kuvaa omaa toimintaansa ja ajatuksiaan äärimmäisen vähän. Toinen samantyyppinen kirjoitus päättyy ensimmäisessä persoonassa lehmän näkökulmasta esitettyyn kertomukseen, mikä korostaa kaunokirjallista vaikutelmaa: "Helkan tarinan loppua ei tiedä kukaan muu kuin Helka itse, joten annan sen (hänen) itse kertoa sen" (SKS KRA. Ei auta sano nauta 6, 7; mies 70 v.). Nämä kirjoitukset tasapainoilevat omakohtaisuuden ja etäännyttämisen kerronnallisten keinojen välimaastossa. Erkki Vainikkala onkin todennut, että taitavasti dramatisoidut kokemukset voivat saada aikaan realistisen kuvitteellisen kerronnan 


\section{TAJJA KaARLENKASKI}

tunnun, jossa aitouden vaikutelma liittyy nimenomaan fiktiolle ominaisin keinoin tuotettuun todenkaltaisuuteen (Vainikkala 1998, 458).

Jatkuvaa preesensin käyttöä kerronnassa, eli niin sanottua dramaattista preesensiä, pidetään kaunokirjallisuuden ja fiktion piirteenä. Ensimmäisen persoonan preesenskerronta on nähty paradoksaalisena kerronnan muotona, koska yleensä ajatellaan, että tapahtumista voi kertoa vasta jälkikäteen, ei tapahtumahetkellä. (Fludernik 1996, 251; Cohn 2006, 116-118.) Preesensiä käyttämällä voi kuitenkin luoda välittömyyden tuntua, vaikutelman siitä, että mennyt olisi läsnä tässä ja nyt (Makkonen 1993, 20). Esimerkiksi kertomuksessa, jossa kuvataan perheenäidin kiireistä päivää lastenhoidossa ja navetassa, jatkuvalla minämuotoisella preesensillä tuotetaan vaikutelmaa tapahtumien hektisyydestä ja suoranaisesta vyörymisestä eteenpäin (SKS KRA. Ei auta sano nauta 273; nainen 50 v.). Tätä ratkaisua voidaan käyttää myös kuvattaessa lapsen kokemusta: maailma esitetään lapsen näkökulmasta ja vaikutelmaa täydennetään lapsenomaisilla ilmaisuilla (SKS KRA. Ei auta sano nauta 2599; nainen 26 v.). Lapsen välittömän kokemuksen kuvaaminen poikkeaa omaelämäkerrallisessa kerronnassa tyypillisesti käytetyistä todentunnun tuottamisen keinoista: kyse ei ole muistelun esittämisestä vaan nykyhetkessä puhuvan lapsisubjektin luomisesta (Lejeune 1989, 53-54). Lapsikertojaa voidaankin käyttää eräänlaisena ulkopuolisena tarkkailijana, joka kyseenalaistaa itsestään selvinä pidettyjä asiantiloja.

Jotkin kerronnalliset keinot, kuten kaikkitietävän kertojan käytön tai jatkuvan minämuotoisen preesensin, voi nähdä eräänlaisina vihjeinä fiktiosta tai kaunokirjallisesta diskurssista. Kirjallisuusfilosofien Peter Lamarquen ja Stein Haugom Olsenin mukaan tekstin voi identifioida kaunokirjalliseksi tai fiktiiviseksi tunnistamalla sen kirjoittajan intentio herättää lukijassaan "kaunokirjallinen vastaanotto" (engl. literary response). Lamarque ja Olsen kutsuvat tätä ilmiötä laajemmin "kaunokirjalliseksi asenteeksi" (engl. literary stance), joka tarkoittaa tekstin tunnistamista kaunokirjalliseksi teokseksi ja sen ymmärtämistä kaunokirjallisen käytännön mukaisesti. (Lamarque \& Olsen 1994, 43-46, 255-256.) Kysymys on siis kirjoittajan ja lukijan vuorovaikutuksesta: kirjoittaja sisällyttää tekstiinsä eräänlaisia kerronnallisia lukuohjeita, jotka tosin voivat olla myös ristiriitaisia ja vaikeasti tulkittavia. Fiktivoidut kertomukset ovatkin muodostamistani kategorioista sisällöltään monipuolisin ja hankalimmin määrittyvä. Näkökulma näissä kertomuksissa on ihmisen, mutta ei välttämättä minäkertojan ja -kokijan muodossa. Fiktivoiduissa kertomuksissa lehmät saattavat olla varsin pienessä roolissa, mutta kuitenkin ne ovat tärkeitä kerronnan motivoijia. Lehmien liepeille voi rakentaa niin romanttisen rakkaustarinan kuin kansantarinaa lähenevän humoristisen kertomuksenkin.

\section{KERTOMUSKATEGORIAT MERKITYSTEN TUOTTAJINA}

Ei auta sano nauta -kilpailun osakseen saama huomio mediassa sekä runsas osallistuminen kertovat siitä, että lehmä koettiin merkittäväksi kerronnan aiheeksi. Tässä kirjoituksessa esittelemäni kertomuskategoriat paljastavat lehmään liitettyjä kulttuurisia representaatioita ja yhteyksiä, joissa lehmä voidaan esittää. Kategoriat voi nähdä 


\section{KERTOMUSKATEGORIAT JA LEHMÄN REPRESENTAATIOT KIRJOITUSKILPAILUTEKSTEISSÄ}

erilaisina lehmään kohdistuvina näkökulmina, jotka merkityksellistävät kerrontaa. Omaelämäkerrallisissa kertomuksissa keskeisiä teemoja ovat kertojan henkilökohtainen suhde nautoihin, karjanhoitoon liittyvät työtehtävät sekä erikoiset tapahtumat. Etnografisissa ja fiktivoiduissa kertomuksissa itse lehmät ovat pikemminkin taustatekijöitä, mutta kertomukset tuovat esiin erilaisia konteksteja ja yhteyksiä, joihin ne voivat liittyä. Näitä ovat esimerkiksi työn ja ympäristön tai vaikkapa maatalouspolitiikan muutosten kuvaukset, ihmissuhteet ja lapsen kokemukset. Lehmänäkökulmaisissa kertomuksissa kokijan positio annetaan muissa kertomuskategorioissa kohteen asemassa olevalle lehmälle. Kertojana ja kokijana lehmä kuitenkin esitetään keskeisiltä piirteiltään ihmisenkaltaisena olentona. Omaelämäkerrallisten kertomusten lehmäpersoonat ja lehmänäkökulmaisissa kertomuksissa esitetyt lehmien "puheenvuorot" representoivat lehmän yksilöllisenä eläimenä, jolla on oma tahto ja luonne. Näiden kategorioiden merkityssisältöjä yhdistää myös nykyisen tehokarjanhoidon kritiikki, jota hahmotetaan sekä ihmisen että naudan näkökulmasta. Omaelämäkerrallisiin, samoin kuin fiktivoituihin kertomuksiin voi yhdistyä piirteitä kaikista muista kertomuskategorioista. Erityyppiset kerronnalliset jaksot luovat erilaisia painotuksia näiden kirjoitusten merkityksiin.

Lehmistä voidaan kertoa niin konkreettisten kokemusten kuin mielikuvienkin tasolla, ja kilpailun aihe on johdattanut osallistujia moninaisten teemojen, keskustelujen ja ilmaisutapojen pariin. Kilpailuun osallistuneet kirjoittajat voi nähdä luovina, näkemyksellisinä yksilöinä, ei niinkään objektiivisuutta tavoittelevina dokumentoijina tai jonkin yhteisön edustajina (Kurki 2004, 82). Yksilöllisyydestä huolimatta kirjoitukset ovat kulttuurisia tekstejä, joissa välittyy kollektiivisia merkityksiä ja kerronnan tapoja. Kirjoittajien omat kokemukset ja näkemykset, kerronnalliset mallit, yleiset puhetavat ja median välittämä kuva kietoutuvat teksteissä yhteen. (Uotinen 2003, 140-141; Laurén 2006, 11.) Esimerkiksi viittaukset yleiseen keskusteluun maatalouden muutoksista ja tehostumispaineista toistuvat teksteissä. Yleisiin käsityksiin viittaavat myös lukuisten kirjoittajien kannanotot siihen, onko nauta tyhmä eläin vai ei. Oma vaikutuksensa tähän pohdintaan on ollut varmasti median lehmäkuvastolla: mainonnassa ja tuotemerkeissä lehmä kuvataan tavallisesti vähintäänkin huvittavana, ellei jopa hölmönä eläimenä.

Kertomusten kategorisointi palvelee paitsi aineiston jäsentäjänä myös tarkemman sisällönanalyysin perustana. Esittelemässäni kategorisoinnissa kirjoitusten merkityksiä ja lehmien representaatioita lähestytään kertomustyyppien kautta. Tällä tavoin voi selvittää aineiston yleispiirteitä, joita on toki tarkennettava muilla analyysimenetelmillä. Myös sisällönanalyysissä esille saadut teemat kannattaa suhteuttaa kertomuskategorioihin. Esimerkiksi yhtä karjanhoidon tärkeimmistä työvaiheista, lypsämistä, voidaan valottaa eri näkökulmista: omaelämäkerrallisissa kertomuksissa kertojan omana kokemuksena, etnografisissa kertomuksissa voidaan kuvata lypsyyn liittyviä välineitä ja tekniikkaa, lehmänäkökulmaisissa kertomuksissa lehmän kokemusta lypsystä ja fiktivoiduissa kertomuksissa voidaan vaikkapa kertoa käsinlypsytilanteesta paikalla olijoiden dialogin avulla. Näin kertomuskonteksti luo merkitystä käsiteltävälle teemalle. Työnteko nautojen parissa onkin yksi aineiston ja kaikki kertomuskategoriat läpäisevistä teemoista, mikä kertoo aiheen merkittävyydestä kirjoittajille. 


\section{TAJJA KaARLENKASKI}

\section{VIITTEET}

(1) Kulttuurituottaja Raija Kallioisen mukaan Maaseudun Sivistysliitto oli Ei auta sano nauta -kilpailun järjestämisessä aloitteellinen osapuoli, ja kaunokirjallinen sarja tuli kilpailuun heidän toivomuksestaan. Maaseudun Sivistysliitossa tilan antaminen myös taiteelliselle kirjoittamiselle nähdään tärkeänä. (Kallioinen 2006.)

(2) Olen valinnut tutkimusaineistoon vain sellaisia tekstejä, jotka ovat suurimmaksi osaksi proosamuodossa. Kokonaan runomuotoiset tekstit olen rajannut aineistoni ulkopuolelle, vaikka runotkin sinänsä voivat sisältää kertovia aineksia. Narratiivinen diskurssi eroaa poeettisesta diskurssista, johon kuuluvat esimerkiksi mitta ja rytmi (Polkinghorne 1995, 6).

(3) Suomalaisessa kielenkäytössä on puhuttu narratiivisesta, kerronnallisesta ja tarinallisesta tutkimuksesta. Tässä kirjoituksessa käytän rinnan narratiivisen ja kerronnallisen tutkimuksen käsitteitä. Nimitystä tarinallinen tutkimus on käytetty esimerkiksi psykologiassa, kasvatustieteissä ja teologiassa (esim. Hänninen 1999; Kekäle 2007). Perinteentutkijana kuitenkin vierastan tätä termiä; onhan tarinalla folkloristiikan käsitteistössä erityismerkityksensä. Myös narratologiassa tarina ja kertomus viittaavat eri asioihin: tarinalla tarkoitetaan kerrottujen tapahtumien kronologista järjestystä sekä tapahtumiin osallistuvia henkilöitä. Asioitahan ei välttämättä kerrota kronologisessa järjestyksessä. (Rimmon-Kenan 1991, 7-8.) On myös syytä muistaa, että narratiivinen tutkimus ei tarkoita samaa kuin narratologia. Tämä kirjallisuudentutkimuksen suuntaus syntyi 1960-luvulla ranskalaisen strukturalismin ja semiotiikan pohjalta. Narratologian tavoitteena oli selvittää kirjallisten kertomusten yhteiset piirteet ja rakenteelliset säännöt. (Herman 1999, 219-220; Kreiswirth 2005, 378-379.) Tutkimussuuntauksen piirissä on kehitetty runsaasti uusia kerronnan rakennetta ja näkökulmia selvittäviä käsitteitä (ks. esim. RimmonKenan 1991), joita on jonkin verran sovellettu myös folkloristiikassa (esim. Apo 1990; Pöysä 2003).

(4) Johtuen siitä, että aineistoa säilytetään yli 400 kilometrin päässä asuinpaikastani, olen lukenut sitä neljänä viikon mittaisena työskentelyjaksona. Jaksottaisen arkistotyöskentelyn takia aineisto on muodostunut kumuloituvasti ja vuorovaikutuksessa arkistokäyntien välillä luetun tutkimuskirjallisuuden ja muun työskentelyn kanssa. Jäsentääkseni lukemistani olen käynyt aineistoa läpi ikäryhmittäin: 20-40-vuotiaat, 40-64-vuotiaat ja yli 64-vuotiaat. Olen myös poiminut luettavaksi kaikista ikäryhmistä sekä karjanhoitoammateissa että aivan muissa ammateissa työskentelevien tai työskennelleiden kirjoituksia varmistaakseni, että aineistoon tulee kattavasti erilaisista lähtökohdista tulevien ihmisten tekstejä. Vaikka en osallistunut kirjoituskilpailun järjestämiseen, tutkimusaineistoa valitessani olen merkittävällä tavalla osallistunut aineiston tuottamiseen ja sen muodostumiseen sellaiseksi kuin se tällä hetkellä on (ks. Uotinen 2005, 95). Tutkimusaineistoon valittujen tekstien kirjoittajat ovat iältään 20-86-vuotiaita, ja kirjoittajista 31 on miehiä ja 95 naisia (naisten osuus 75 prosenttia). Kaikista kirjoituskilpailuun osallistuneista naisia oli 78 prosenttia.

(5) Esimerkiksi Pauliina Latvalan jaottelu elämästä kertomisen, historiasta kertomisen, sukupolvista kertomisen sekä fiktiivisen kirjoittamisen ja suullisen kerronnan 


\section{KERTOMUSKATEGORIAT JA LEHMÄN REPRESENTAATIOT KIRJOITUSKILPAILUTEKSTEISSÄ}

malleihin (Latvala 2005, 71-78) sekä Kirsi Laurénin (2006, 73-76) erottamat kokemus- ja elämyskertomukset.

(6) Muisteluprosessin tuloksena syntyneistä henkilökohtaisista aineistoista on käytetty myös muun muassa termejä elämänkertomus, henkilökohtainen kerronta, muistelu ja kokemuskerronta (esim. Siikala 1984, 142-143; Peltonen 1996, 39-47; Ukkonen 2000, 21-27; Korkiakangas 2005, 133). Tämäntyyppiseen kerrontaan on viitattu väljemmin myös muistitietona. Kaikkiin näihin termeihin liittyy jollakin tasolla oletus kerrotun viittaamisesta todella tapahtuneeseen tai koettuun. Omaelämäkerta on kuitenkin termi, jota käytetään myös kirjallisuudentutkimuksessa, ja monet omaelämäkerran kaanoniin kuuluvat julkaistut teokset käyttävät tietoisesti fiktion keinoja sekä kaunokirjallisuudelle tyypillistä esteettistä ilmaisua.

(7) Ei auta sano nauta -kirjoituskilpailun vastaukset on tallennettu Suomalaisen Kirjallisuuden Seuran kansanrunousarkistoon. Kirjoitukset on arkistoitu ja numeroitu saapumisjärjestykseen. Viittaan teksteihin tunnuksella SKS KRA. Ei auta sano nauta, kirjoituksen järjestysnumerolla ja sisäisellä sivunumeroinnilla. Lisäksi merkitsen kirjoittajan sukupuolen ja iän kirjoitushetkellä. Tarkemmat tiedot viitatuista kirjoituksista löytyvät aineistoluettelosta.

(8) Etnografiaa voidaan toki kirjoittaa myös minämuodossa. Määrittelen etnografisen kerronnan tässä passiivia suosivaksi ja etäännyttäväksi erottaakseni sen omaelämäkerrallisesta kerronnasta.

(9) Narratologiassa suositaan fokalisaation käsitettä epämääräisemmän näkökulman käsitteen sijasta. Fokalisoija on "tietoisuuden keskus", jonka silmin kerrotut asiat nähdään, eli fokalisoija ei välttämättä ole sama kuin kertoja. (Rimmon-Kenan 1991, 92-95; Abbott 2008, 73-74.)

(10) Kaunokirjallisuus- ja fiktio-termejä käytetään joissain tilanteissa synonyymisinä, mutta välttämättä näin ei ole, kuten Heikki Kujansivu (2002, 274) on huomauttanut: "[K]aikki kirjallisuus ei välttämättä ole kaunokirjallisuutta, eikä kaikki kaunokirjallisuus fiktiota" (ks. myös Eagleton 1996, 9).

\section{LÄHTEET}

\section{Arkistoaineisto}

Suomalaisen Kirjallisuuden Seuran Kansanrunousarkisto, Ei auta sano nauta - kirjoituskilpailu lehmästä 2004.

Artikkelissa on viitattu seuraaviin kirjoituksiin:

- SKS KRA. Ei auta sano nauta 6. Mies, 70 vuotta, Ristiina, 8 sivua.

- SKS KRA. Ei auta sano nauta 20. Mies, 67 vuotta, Tervola, 6 sivua.

- SKS KRA. Ei auta sano nauta 79. Mies, 83 vuotta, Heinola, 5 sivua.

- SKS KRA. Ei auta sano nauta 149. Nainen, 86 vuotta, Multia, 7 sivua.

- SKS KRA. Ei auta sano nauta 265. Mies, 78 vuotta, Posio, 10 sivua. 


\section{TAJJA KaARLENKASKI}

- SKS KRA. Ei auta sano nauta 273. Nainen, 50 vuotta, Konnevesi, 4 sivua.

- SKS KRA. Ei auta sano nauta 295. Mies, 58 vuotta, Kiuruvesi, 5 sivua.

- SKS KRA. Ei auta sano nauta 328. Nainen, 40 vuotta, Kortesjärvi, 9 sivua.

- SKS KRA. Ei auta sano nauta 390. Nainen, 72 vuotta, Kuhmoinen, 4 sivua.

- SKS KRA. Ei auta sano nauta 487. Nainen, 35 vuotta, Kärsämäki, 7 sivua.

- SKS KRA. Ei auta sano nauta 537. Nainen, 28 vuotta, Kouvola, 5 sivua.

- SKS KRA. Ei auta sano nauta 680. Mies, 29 vuotta, Kylmäkoski, 10 sivua.

- SKS KRA. Ei auta sano nauta 762. Mies, 72 vuotta, Kangasala, 10 sivua.

- SKS KRA. Ei auta sano nauta 763. Mies, 72 vuotta, Kangasala, 10 sivua.

- SKS KRA. Ei auta sano nauta 1419. Nainen, 54 vuotta, Kiuruvesi, 3 sivua.

- SKS KRA. Ei auta sano nauta 2519. Nainen, 20 vuotta, Elimäki, 5 sivua.

- SKS KRA. Ei auta sano nauta 2599. Nainen, 26 vuotta, Vantaa, 4 sivua.

- SKS KRA. Ei auta sano nauta 2818. Nainen, 34 vuotta, Oulu, 7 sivua.

\section{Painamattomat lähteet}

Ei auta sano nauta. Kirjoituskilpailu lehmästä. Kirjoituskilpailuesite, 2004. Maaseudun Sivistysliitto \& Suomalaisen Kirjallisuuden Seura. Saatavilla myös verkossa: < http:/ / www.finlit.fi/kra/keruut/nauta.htm > [18.6.2008.]

KALLIOINEN 2006. Maaseudun Sivistysliiton kulttuurituottaja Raija Kallioisen sähköpostitiedonanto tutkimuksen tekijälle 24.4.2006.

MAASEUDUN SIVISTYSLIITTTO 2008. Esittely [online]. < http://www.msl.fi/ $>$ [16.5.2008.]

NIRKKO 2006. Suomalaisen Kirjallisuuden Seuran Kansanrunousarkiston tutkija Juha Nirkon sähköpostitiedonanto tutkimuksen tekijälle 19.4.2006.

\section{Kirjallisuus}

ABBOTT, H. PORTER 2008: The Cambridge Introduction to Narrative. Cambridge: Cambridge University Press. [2002]

APO, SATU 1990: Kertomusten sisällön analyysi. - Mäkelä, Klaus (toim.), Kvalitatiivisen aineiston analyysi ja tulkinta. Helsinki: Gaudeamus.

- 1995: Naisen väki. Tutkimuksia suomalaisten kansanomaisesta kulttuurista ja ajattelusta. Helsinki: Hanki ja jää.

— 2001: Viinan voima. Näkökulmia suomalaisten kansanomaiseen alkoholiajatteluun ja -kulttuuriin. Helsinki: Suomalaisen Kirjallisuuden Seura.

COHN, DORRIT 2006: Fiktion mieli. Helsinki: Gaudeamus. [1999]

DASTON, LORRAINE \& MITMAN, GREGG 2005: Introduction. The How and Why of Thinking with Animals. - Daston, Lorraine \& Mitman, Gregg (eds.), Thinking with Animals. New Perspectives on Anthropomorphism. New York: Columbia University Press. 


\section{KERTOMUSKATEGORIAT JA LEHMÄN REPRESENTAATIOT KIRJOITUSKILPAILUTEKSTEISSÄ}

EAGLETON, TERRY 1996: Literary Theory. An Introduction. Minneapolis: University of Minnesota Press. [1983]

FLUDERNIK, MONIKA 1996: Towards a "Natural" Narratology. London: Routledge.

HATAKKA, MARI 2004: 'Kun on tunteet". Lukemisen kokemus metodisena mahdollisuutena. - Kurki, Tuulikki (toim.), Kansanrunousarkisto, lukijat ja tulkinnat. Helsinki: Suomalaisen Kirjallisuuden Seura.

HEIKKINEN, HANNU L. T. 2000: Tarinan mahti - narratiivisuuden teemoja ja muunnelmia. - Tiedepolitiikea 26(4).

HELSTI, HILKKA 2005: Hedelmällisen tiedon jäljillä - teemakirjoitukset tutkimuksen lähteinä. - Korkiakangas, Pirjo \& Olsson, Pia \& Ruotsala, Helena (toim.), Polkuja etnologian menetelmiin. Helsinki: Ethnos ry.

HERMAN, DAVID 1999: Toward a Socionarratology: New Ways of Analyzing Natural-Language Narratives. - Herman, David (ed.), Narratologies: New Perspectives on Narrative Analysis. Columbus: Ohio State University Press.

HOSIAISLUOMA, YRJÖ 2003: Kirjallisunden sanakirja. Helsinki: WSOY.

HYNNINEN, ANNA 2004: Toisto ja variaatio omaelämäkerrallisessa kerronnassa. - Elore 11(2) [online]. < http://www.elore.fi/arkisto/2_04/hyn204.html > [5.12.2007.]

HYVÄRINEN, MATTI 2006: Kerronnallinen tutkimus [online]. < http:/ /www.hyvarinen.info/pdf/Webkertomus\%5B1\%5D.06.2.pdf > [14.11.2007.]

HÄNNINEN, VILMA 1999: Sisäinen tarina, elämä ja muntos. Tampere: Tampereen yliopistopaino.

JOKINEN, KIMMO 1997: Suomalaisen lukemisen maisemaihanteet. Jyväskylä: Jyväskylän yliopisto.

KEKÄLE, JARI 2007: Postmoderni isyys ja uskonnollisuus - tarinallinen näkö̈ulma. Joensuu: Joensuun yliopisto.

KORKIAKANGAS, PIRJO 2005: Muistoista tulkintaan - muisti ja muisteluaineistot etnologian tutkimuksessa. - Korkiakangas, Pirjo \& Olsson, Pia \& Ruotsala, Helena (toim.), Polkuja etnologian menetelmiin. Helsinki: Ethnos ry.

KORSISAARI, EVA MARIA 2003: Keskeisiä kirjallisuudentutkimuksen suuntauksia. - Alanko, Outi \& Käkelä-Puumala, Tiina (toim.), Kirjallisundentutkimukesen peruskäsitteitä. Helsinki: Suomalaisen Kirjallisuuden Seura. [2001]

KREISWIRTH, MARTIN 2005: Narrative Turn in the Humanities. - Herman, David \& Jahn, Manfred \& Ryan, Marie Laure (eds.), Routledge Encyclopedia of Narrative Theory. London: Routledge.

KUJANSIVU, HEIKKI 2002: Faktissi ja lukemisen riski - Max Applen "An Offering" ja fiktionaalisuus. - Lehtimäki, Markku (toim.), Merkkejä ja symboleja. Esseitä kirjallisundesta ja sen tutkimuksesta. Tampere: Tampere University Press.

KURKI, TUULIKKI 2004: Tekstit kansanrunousarkiston liepeillä. - Kurki, Tuulikki (toim.), Kansanrunousarkisto, lukijat ja tulkinnat. Helsinki: Suomalaisen Kirjallisuuden Seura.

LAMARQUE, PETER \& OLSEN, STEIN HAUGOM 1994: Truth, Fiction and Literature. A Philosophical Perspective. Oxford: Clarendon Press. 


\section{TAJJA KaARLENKASKI}

LATVALA, PAULIINA 2002: Ethical Issues in the Research on Written Life History Material. - Anepaio, Terje \& Kaalep, Tuuli \& Sikka, Toivo (eds.), Ethics in Cultural Studies. Pro Ethnologia 13.

- 2005: Katse menneisyyteen. Folkloristinen tutkimus suvun muistitiedosta. Helsinki: Suomalaisen Kirjallisuuden Seura.

LAURÉN, KIRSI 2006: Suo-sisulla ja sydämellä. Suomalaisten suokokemuksetja -kertomukset kulttuurisen luontosubteen ilmentäjinä. Helsinki: Suomalaisen Kirjallisuuden Seura.

LEHTIMÄKI, MARKKU 2000: Faktuaalisen narratiivin etiikka ja poetiikka. Esimerkkinä Norman Mailerin ei-fiktiivinen romaani The Executioner's Song. - Hallila, Mika \& Krogerus, Tellervo (toim.), Rajatapanksia. Helsinki: Suomalaisen Kirjallisuuden Seura.

LEHTONEN, MIKKO 2004: Merkitysten maailma. Kulttuurisen tekstintutkimuksen lähtökobtia. Tampere: Vastapaino. [1996]

LEJEUNE, PHILIPPE 1989: On Autobiography. Minneapolis: University of Minnesota Press.

LYYTIKÄINEN, PIRJO 2005: Esipuhe. Lajit kirjallisuudessa. - Lyytikäinen, Pirjo \& Nummi, Jyrki \& Koivisto, Päivi (toim.), Lajit yli rajojen. Suomalaisen kirjallisunden lajeja. Helsinki: SKS.

MAKKONEN, ANNA 1993: "Lukijani, lähdetkö mukaani?" Lajitietoisuus naisten omaelämäkerroissa. - Piela, Ulla (toim.), Aikanaisia. Kirjoituksia naisten omaelämäkerroista Helsinki: Suomalaisen Kirjallisuuden Seura.

PELTONEN, ULLA-MAIJA 1996: Punakapinan muistot. Tutkimus työväen muistelukerronnan muotoutumisesta vuoden 1918 jälkeen. Helsinki: Suomalaisen Kirjallisuuden Seura.

POLKINGHORNE, DONALD E. 1995: Narrative Configuration in Qualitative Analysis. - Hatch, J. Amos \& Wisniewski, Richard (eds.), Life History and Narrative. London: Falmer Press.

PORTELLI, ALESSANDRO 1998: Oral History as Genre. - Chamberlain, Mary \& Thompson, Paul (eds.), Narrative and Genre. London: Routledge.

PÖYSÄ, JYRKI 1997: Jätkän synty. Tutkimus sosiaalisen kategorian muotoutumisesta itäsuomalaisessa metsätyöperinteessä. Helsinki: Suomalaisen Kirjallisuuden Seura.

— 2003: Tietokone - isäntä vai renki? Analyysi retrospektiivisen muistelun rakenteista kilpakirjoitusaineistossa. - Talja, Sanna \& Tuuva, Sari (toim.), Tietotekniikkeasubteet. Kulttuurinen näkökulma. Helsinki: Suomalaisen Kirjallisuuden Seura.

— 2006: Kilpakirjoitukset muistitietotutkimuksessa. - Fingerroos, Outi \& Haanpää, Riina \& Heimo, Anne \& Peltonen, Ulla-Maija (toim.), Muistitietotutkimus. Metodologisia kysymyksiä. Helsinki: Suomalaisen Kirjallisuuden Seura.

PÖYSÄ, JYRKI \& TIMONEN, SENNI 2004: Kuinka ahkerat muurahaiset saivat kasvot? Henkilökohtaisen tiedon paikka arkiston keruuohjeissa. - Kurki, Tuulikki (toim.), Kansanrunousarkisto, lukijat ja tulkinnat. Helsinki: Suomalaisen Kirjallisuuden Seura.

RIESSMAN, CATHERINE KOHLER 1993: Narrative Analysis. Newbury Park, London: Sage Publications.

RIMMON-KENAN, SHLOMITH 1991: Kertomuksen poetiikeka. Helsinki: Suomalaisen Kirjallisuuden Seura. [1983] 


\section{KERTOMUSKATEGORIAT JA LEHMÄN REPRESENTAATIOT KIRJOITUSKILPAILUTEKSTEISSÄ}

ROOS, JEJA-PEKKA 1987: Suomalainen elämä. Tutkimus tavallisten suomalaisten elämäkerroista. Helsinki: Suomalaisen Kirjallisuuden Seura.

ROTHFELS, NIGEL 2002: Introduction. - Rothfels, Nigel (ed.), Representing Animals. Bloomington: Indiana University Press.

SALMI-NIKLANDER, KIRSTI 2004: Itsekasvatusta ja kapinaa. Tutkimus Karkkilan työläisnuorten kirjoittavasta keskusteluybteisöstä 1910-ja 1920-lwouilla. Helsinki: Suomalaisen Kirjallisuuden Seura.

SARESMA, TUIJA 2007: Omaelämäkerran rajapinnoilla. Kuolema ja kirjoitus. Jyväskylä: Jyväskylän yliopisto.

SIIKALA, ANNA-LEENA 1984: Tarina ja tulkinta. Tutkimus kansankertojista. Helsinki: Suomalaisen Kirjallisuuden Seura.

TAIRA, TEEMU 2006: Työkulttuurin arvomuutos työttömien kerronnassa. Helsinki: Suomalaisen Kirjallisuuden Seura.

TARKKA, LOTTE 2005: Rajarahvaan laulu. Tutkimus Vuokkiniemen kalevalamittaisesta runokulttuurista 1821-1921. Helsinki: Suomalaisen Kirjallisuuden Seura.

UKKONEN, TAINA 2000: Menneisyyden tulkinta kertomalla. Muistelupube oman bistorian ja kokemuskertomusten tuottamisprosessina. Helsinki: Suomalaisen Kirjallisuuden Seura.

- 2003: Kertomisen voima. - Elore 10(2) [online]. < http://www.elore.fi/arkisto/2_03/ukk203.html > [22.1.2008.]

UOTINEN, JOHANNA 2003: "Agricolan päivänä se kannettiin meidän makuuhuoneen pöydälle.” Tietotekniikka, kokemus ja kertomus. - Talja, Sanna \& Tuuva, Sari (toim.), Tietotekniikkeasubteet. Kulttuurinen näkökulma. Helsinki: Suomalaisen Kirjallisuuden Seura.

- 2005: Merkillinen kone. Informaatioteknologia, kokemus ja kertomus. Joensuu: Joensuun yliopisto.

VAINIKKALA, ERKKI 1998: Minä, lukijani, kaltaiseni! Ajatuksia kerronnasta, autobiografiasta ja Likasta. - Eskola, Katarina (toim.), Elämysten jäljillä. Taide ja kirjallisuus suomalaisten omaelämäkerroissa. Helsinki: Suomalaisen Kirjallisuuden Seura.

WOLF, WERNER 2007: Description as a Transmedial Mode of Representation. General Features and Possibilities of Realization in Painting, Fiction and Music. - Wolf, Werner \& Bernhart, Walter (eds.), Description in Literature and Other Media. Amsterdam \& New York: Rodopi.

Filosofian maisteri Taija Kaarlenkaski on tutkijakoulutettava Kulttuuristen tulkintojen tutkijakoulussa ja perinteentutkimuksen jatko-opiskelija Joensuun yliopistossa. 